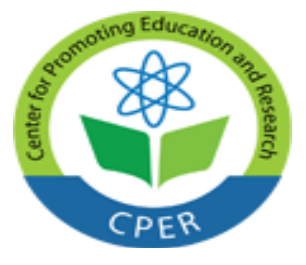

VOL: 5, ISSUE: 2

February/2019

E-ISSN: 2469-6501

(C) Center for Promoting Education and Research (CPER) USA

WWW.cpernet.org

\title{
Application of Technology in Mitigating Refined Petroleum Shortages in the Nigerian Downstream Petroleum Supply Industry
}

\author{
Itsekor Lucky Ubini (DBA) \\ College of Management and Technology \\ Walden University, Minneapolis, USA \\ Phone: +2348060317984 \\ Email: dr.litsekor@gmail.com \\ USA
}

Abstract

\begin{abstract}
Nigeria operates a petroleum-based economy but suffers refined product shortages. The continual shortages or scarcity of refined petroleum products cripples business activities, which undermines the development of the Nigerian economy. The purpose of this multiple case study was to identify the strategic role of technology application in mitigating petroleum shortages in the petroleum supply chain and to sustain business development in Nigeria. The research participants include ten senior leaders from two private-sector Nigerian downstream petroleum supply companies located in the Niger Delta region, who had successfully implemented strategies for petroleum supply. The conceptual framework for the research was the resource based view theory. Data collection was through semi structured face-to-face interviews and review of company's operational and policy documents. Data validation was through member checking and triangulation, after transcription and analysis. The findings indicate that the oil and gas industry is technologically driven, and for efficiency and effectiveness of supply, petroleum leaders should apply required technology in all segment of the supply chain; (operations) vessel or marine, discharge operations, tank farm operations, logistics, and retail outlets, (no operations) administration, sales, safety, IT, finance, and marketing. Findings may be used by petroleum business leaders and investors to create effective and efficient technological resource management strategies in the supply chain, leading to product availability, sustainability, poverty reduction, and economic development.
\end{abstract}

\section{Keywords: Petroleum shortages, Nigerian downstream, Private sector depot, Technology, Business development, Supply chain, Marketing, Scarcity}

\subsection{Introduction}

Nigeria is a major oil producer, ranking sixth among oil-producing nations in the world (Aminu \& Olawore, 2014; Oladepo, 2014). Nigeria is a leading member of the organization of petroleum exporting countries (OPEC), with large reserves of oil. However, Nigeria suffers from a shortage of refined petroleum products (Aminu \& Olawore, 2014). Nigeria is the only OPEC member that relies heavily on importation to meet local demand (Aminu \& Olawore, 2014; Chigbu et al., 2016). Nigeria imports $80 \%$ of petroleum products to meet local demand (Aminu \& Olawore 2014; Oladepo, 2014).

An acute shortage of petroleum products is consistent with the Nigerian petroleum industry (Aminu \& Olawore, 2014; Chigbu et al., 2016). Aminu and Olayinka (2014) attributed high levels of petroleum consumption in Nigeria to increasing population, economic growth, an increase in vehicular traffic, inadequate supply of electricity, low price of fuel, and lack of petrol tax. Furthermore, Alaba and Agbalajobi (2014) affirmed that the supply and distribution of petroleum products in Nigeria is bedevilled by crises, irregular supply, shortages, 


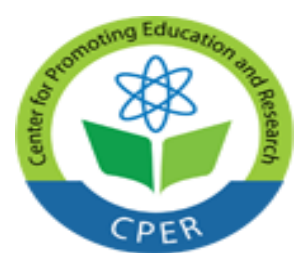

VOL: 5, ISSUE: 2

February/2019

E-ISSN: 2469-6501

(C) Center for Promoting Education and Research (CPER) USA

WWW.cpernet.org

hoarding, smuggling, adulteration, and long queues. The petroleum product scarcity is associated with low refining output, inadequate pipeline infrastructure, pipeline vandalism and rupture, existing state-owned moribund refineries, and lack of adequate technology for turnaround maintenance on petroleum infrastructures (Adelabu, 2012; Aminu \& Olawore, 2014).

The application of technology in the oil and gas industry is sacrosanct. However, Nigeria does not have the basic technology to effectively and efficiently manage the supply chain of the NDPSI (Monday, 2015). The application of technology to every segment of the NDPSI business, whether operational or nonoperational is required to achieve supply efficiency. The operational segment involves the core supply chain activities such as Marine, depot storage, logistics, and retail outlets operations, while the nonoperational segment involves all operations support such as administration, marketing, sales, IT, engineering, and safety operations.

The purpose of this article is to identify the strategic role of technology in the downstream petroleum supply chain to mitigate shortages and improve business development in Nigeria. The results of this research may provide petroleum organizational leaders with sustainable supply chain management (SCM) strategies regarding the contribution of improved technology for increased business development, increased revenue, job creation, and enhanced economic growth.

\subsection{Conceptual Framework}

Technology is a key resource in the oil and gas business. The conceptual framework for this research was the resource based view theory (RBV). Barney (1991) affirmed that to achieve sustainable competitive advantage, leaders of a firm must acquire resources (a) for developing effective and efficient strategies, (b) scarce in the industry, (c) that are imperfectly imitable, and (d) non substitutable in the industry. The resources include reputational, financial, physical, human, and technological resources. Furthermore, Crook and Esper(2014) and Zimmermann and Foerstl(2014) noted that Leaders can apply RBV to optimize resources to create value, leading to organizational effectiveness and efficiency.

The application of technology in both operational and nonoperational segments of firms in the NDPSI is strategic to the success of the organizations. Applying RBV to operations strategy involves the use of technology to develop, protect, and leverage a firm's unique resources towards achieving competitive advantage (Hitt et al., 2016). RBV stressed that firms need to build capabilities for coordination and incorporation of physical and information flow among the different segment of a supply chain (Sancha, Longoni, \& Giménez, 2015).

\subsection{A Review of the Professional and Academic Literature}

\subsection{An overview of the Nigerian downstream oil and gas industry}

The Nigerian oil and gas industry consists of the upstream sector, the midstream sector, and the downstream sector (Aminu \& Olawore, 2014; NNPC, 2016). The upstream industry is the sector charged with exploration, exploitation, and production of crude oil. The midstream sector is responsible for refining and storage of products. The downstream sector's activities involve marketing, distribution, and transportation of refined petroleum products from the refineries or import jetties to retail outlets or points of consumption (NNPC, 2015; Osuala, 2013).

The downstream industry powers the Nigerian economy through the provision of products for transportation and energy, employment generation, and wealth creation (Aminu \& Olawore, 2014). Because of mismanagement and misallocation of resources, the Nigerian oil and gas downstream sector have not lived up to expectation (Ambituuni et al., 2014; Gonzalez, 2016; Okwanya et al., 2015). The sector experienced gross inefficiencies, which crippled business development through the nation (Chigbu et al., 2016; Osuala, 2013). Nigerian downstream petroleum inefficiencies include a perennial shortage of refined petroleum products, 


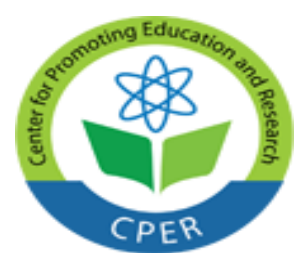

VOL: 5, ISSUE: 2

February/2019

E-ISSN: 2469-6501

(C) Center for Promoting Education and Research (CPER) USA

WWW.cpernet.org

product diversion, product adulteration, abnormal product subsidy, underutilized refineries, refinery sabotage, pipeline breakage, product theft, corruption, inadequate technological knowhow, and sharp practices in retail outlets (Adelabu, 2012; Chigbu et al., 2016; Osuala, 2013).

The continual shortage or scarcity of petroleum products in Nigeria has a multiplier effect on almost all sectors of the economy, which has given rise to some abnormal business practices in the downstream petroleum supply chain (Adelabu, 2012; Chigbu et al., 2016). The abnormal business activities contribute negatively to product supply sustainability and enhance scarcity (Osuala, 2013). The abnormal business activities include (a) retail outlet inefficiencies, (b) product diversion and cross-border smuggling, and (c) pipeline interdiction and stealing of nation's products.

\subsubsection{Retail outlet inefficiencies.}

Retail outlet inefficiencies are abnormal practices by retail outlet managers aimed at making an extra profit during products scarcity situations (Odeh,2011). Specifically, retail outlet inefficiencies include overpricing of products, hoarding of products, product adulteration, and sharp practices (Adelabu, 2012; Odeh 2011). Product hoarding refers to the unlawful hiding of products from the consumers at a required demand period (Osuala, 2013). With the continual petroleum product shortages, dealers of retail outlets hoard products to sell at higher prices (Okwanya et al., 2015) during leaner times. Consumers buy these products at a higher price or through the black market process. The higher price translates into higher cost of doing business, thereby reducing or eliminating profit, which eventually cripples both upcoming and existing enterprises (Okwanya et al., 2015).

Petroleum product adulteration refers to diluting a quality-refined product with a less quality product to increase the volume for more profit (Vempatapu \& Kanaujia,2017). Because of shortages of refined petroleum products, unscrupulous individuals or organizations indulge in adulteration of petroleum products to achieve higher gains or profits (Adelabu, 2012). Vempatapu and Kanaujia (2017) affirmed that the resultant effect of product adulteration can be damaging to machine and vehicle engines, leading to fatality and higher cost of business. Product adulteration can result in an explosion, leading to loss of lives (Vempatapu \& Kanaujia, 2017). Sharp practices are abnormal activities conducted at retail outlets by either the station managers, sales attendants, or the dealers of the stations (Aminu \& Olawore, 2014; Odeh, 2011).

Sharp practices aim to extort money from consumers or make abnormal profits by petroleum retail organizations (Odeh, 2011). Sharp practices include adjustment of meters tolerance level, under-dispensing of products, a collection of money at the entrance of retail stations, short-changing customers and black market activities within the retail outlet (Aminu \& Olawore 2014). These activities are prevalent whenever scarcity persists. The regulatory authorities such as the civil service commission and the Department of Petroleum Resources (DPR) attempt to curb these activities (DPR, 2016). Sharp practices eventually lead to high cost of the product, which translates to a high cost of doing business.

\subsubsection{Product diversion and cross-border smuggling.}

Product diversion occurs when a product meant for a specific destination changes to another destination (David, Harrak, Mills, \& Ocampus, 2014; Osuala, 2013). For example, re-directing a product meant for a retail station in an urban environment to a rural environment. The selling price in the new destination may be much higher than the originally allocated destination (Chigbu et al., 2016). This differs from cross-border smuggling in that the product consumption takes place within Nigeria. The result is that scarcity will loom in the original destination, creating business problems. David et al. (2014) affirmed that price variation of petroleum products occur within a country. 


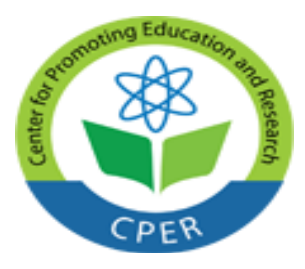

VOL: 5, ISSUE: 2

February/2019

E-ISSN: 2469-6501

(C) Center for Promoting Education and Research (CPER) USA

WWW.cpernet.org

Cross-border smuggling is the process of illegally transporting refined petroleum products, meant for domestic consumption in Nigeria, to neighboring countries (David et al., 2014; Osuala, 2013). According to David et al. (2014), smugglers and unregistered traders exploit price differentials across countries in Western Africa. Smuggling between Nigeria and Togo cost a loss to the Togo government of 23 million Euros per year (David et al., 2014). Economic forces drive prices within this region rather than market forces (David et al., 2014). As an oil producing country, petroleum product costs lower in Nigeria compared to neighboring countries (Chigbu et al., 2016; David et al., 2014). Dealers capitalize on the price differential to sell the products at higher prices to neighboring countries, resulting in product scarcity in Nigeria, which hampers business development (Osuala, 2013).

\subsubsection{Pipeline interdiction and Niger Delta activities.}

The pipeline networks represent critical infrastructural facility for the Nigerian oil and gas industry and are pivotal to sustaining energy supply and economic growth (Chigbu et al., 2016). In Nigeria, pipeline interdiction is one of the major causes of refined petroleum product shortages (Aminu \& Olayinka, 2014). Pipeline interdiction occurs when no natural causes lead to pipeline breakage (Anifowose et al., 2014).

Ambituuni, Amezaga, \& Werner (2015) and Anifowose et al. (2014) reiterated that the main modes of petroleum transportation are through road trucking and pipeline. The Nigeria pipeline network has exceeded the designated lifespan and prone to corrosion and rusting (Anifowose et al., 2014). Rusting and corrosion often lead to pipeline breakages, causing pollution and product shortages in different parts of the country (Anifowose et al., 2014).

Igbinovia (2014) researched thieves breaking pipelines to siphon petroleum products, damaging both the economy and the environment. Igbinovia reported that oil theft in Nigeria hit a record high in the first quarter of 2013, a loss of U.S. $\$ 1.2$ billion. Criminals cut off crude oil supplies to the refineries thereby shutting down production at the refineries. The net effect is a lack of refined products, leading to petroleum scarcity.

The most productive region of oil in Nigeria is the Niger Delta region (Enuoh \& Inyang, 2014; Gonzalez, 2016; Tobor, 2014). The Niger Delta inhabits about 30 million people, has 48 oil fields, 93 national gas fields, a reserve of 34.5 billion barrel of oil and 94 trillion cubic feet of gas (Enuoh \& Inyang, 2014; Gonzalez, 2016; Tobor, 2014). According to Tobor (2014), the Niger Delta region has 33 billion barrels of crude oil and 163 trillion cubic meters of gas reserves. The Niger Delta region has yielded over $\$ 600$ billion from petroleum since 1956, yet the Niger Delta region is in penury (Enuoh \& Inyang, 2014).

Multinational oil companies (MNC) operating in the Niger Delta have not met the expectations of the local communities regarding resources distribution (Enuoh \& Inyang, 2014; Tobor, 2014). Tobor (2014) and Enuoh and Inyang (2014) affirmed that the MNC did not treat the inhabitants of the communities like stakeholders. Basic infrastructures such as roads, water, hospitals, and schools lack in areas of oil production (Akinwotu, 2014; Enuoh \& Inyang, 2014). The inhabitants of the Niger Delta live in penury while the multinational companies smile to the banks (Enuoh \& Inyang, 2014; Tobor, 2014). Multinational companies have the responsibility to address social issues in their areas of operations (Maniruzzaman \& Jasimuddin, 2016). Pollution by MNC has brought penury to the lands in the Niger Delta thereby prompting youth to be involved in illegal activities (Enuoh \& Inyang, 2014; Tobor, 2014).The resultant effect is civil unrest, militancy, social disorder, and disruption of the flow of crude oil supplies to refineries, leading to production shut down and hence supply shortages (Enuoh \& Inyang, 2014). Nigerian deregulation and supply strategy implementation can only come into fruition if the business environment is conducive and stable (Ijiaya, 2014).

The Niger Delta has a proliferation of arms and light weapons (Wilson, 2014). Militants in Niger Delta create wealth through bunkering activities thereby reducing or cutting off crude supplies to refineries (Enuoh \& 


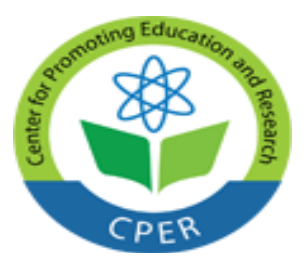

VOL: 5, ISSUE: 2

February/2019

E-ISSN: 2469-6501

(C) Center for Promoting Education and Research (CPER) USA

WWW.cpernet.org

Inyang, 2014). Militants attack on oil installation reduces government income, which affects the supply of petroleum products across the West African region (Tobor, 2014). The resultant effect is production shortages and scarcity of refined petroleum products.

\subsection{Economy and business development.}

Crude oil business has improved the world economy since the 1960s (Dulami, 2014). The supply and price volatility of crude oil have a direct developmental effect on nations' economies (Fowowe, 2014). David, Harrak, Mills, and Ocampus (2014) posited that international oil price volatility determines the national retail price of petroleum products across the world. The Nigerian economy and business development depends directly on the activities of the oil and gas industry (Akinwotu, 2014; Osuala, 2013)

The increase in the price of world oil and petroleum products affects business development and quality of life in developing economies like Nigeria (Alimi \& Fatukasi, 2014). Alimi and Fatukasi (2014) asserted that end users take the responsibility of increasing world petroleum prices without changes in government taxes or subsidies. Poverty has increased, and future businesses activity has been negatively affected (Adelabu, 2012; Chigbu et al., 2016). Further, the higher cost of imported petroleum products, such as in Nigeria, leads to an increase in the external country spending and underdevelopment of the local economy (Okwanya et al., 2015).

Notwithstanding the high revenues derived from oil and gas sales, Nigeria lacks a sustainable business economy (Akinwotu, 2014; Gonzalez, 2016; Tobor, 2014). Ambituuni et al. (2014) and Anyanwu and Erhijakpor (2014) noted that Nigeria has no master plan for achieving sustainable economic growth using proceeds from oil and gas resources; therefore, the nation's economy is grossly underdeveloped. The Nigerian business economy is characterized by poor electricity, low-level infrastructure, bad roads, and continuous refined petroleum shortages (Akinwotu, 2014; Okwanya et al., 2015). To achieve sustainable business development and grow the Nigerian economy, Chigbu et al.(2016) noted that adequate private partnership must be involved in the business of NDPSI.

\subsection{Technological resources in Nigerian Downstream Petroleum supply Industry.}

Nigeria lacks the basic technological resources to effectively and efficiently manage the NDPSI (Monday, 2015). An indicator of technological underdevelopment in Nigeria is the failure to indigenize science and technology and the inability to maintain high technology standards (Olukoju, 2014). Because of the lack of technological knowhow, oil infrastructures and facilities remain in a state of disrepair and moribund (Monday, 2015; Oladepo, 2014). Examples can be noted by the state of refineries, pipelines and reception facilities at the jetties (Aminu\& Olawore, 2014).

The Nigerian government has spent billions of dollars on refinery maintenance without success (Aminu \& Olawore, 2014). Adelabu (2012) and Aminu and Olawore (2014) affirmed that about $\$ 400 \mathrm{~m}$ was used on rehabilitation of refineries within the 2000s without positive results. Nigeria imports technological experts and engineering firms for major construction works in the NDPSI, especially for repair of refineries and turn around maintenance, to enhance the supply of refined petroleum products (Olukoju, 2014). Monday (2015) affirmed the shortage of technological personnel in the NDPSI as a major factor affecting the performance of refineries and hence, the short supply of refined petroleum products in Nigeria. Furthermore, Aminu and Olawore (2014) advised policymakers and leaders to employ technology in addressing problems of the NDPSI.

\subsection{Research Method and Design}

One of the research methods used in exploring human experience regarding a phenomenon is the qualitative research method (Harrison, 2013). I used the qualitative method for this research. According to 


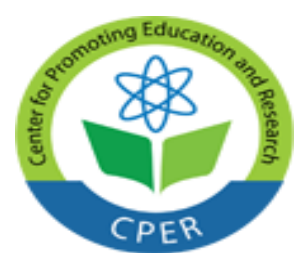

VOL: 5, ISSUE: 2

February/2019

E-ISSN: 2469-6501

(C) Center for Promoting Education and Research (CPER) USA

WWW.cpernet.org

Marshall and Rossman (2016), researchers generate detail perspective of a problem by applying qualitative research methods.

I used a case study design for this research. A case study design requires the collection of data from multiple sources. Punch (2013) affirmed that researchers use a case study design to provide multiple views of real-world context and enhance social change.

\subsection{Study Population and Sample}

I applied the purposeful sampling technique to select 10 petroleum business leaders ( 5 each) from two privately-owned downstream petroleum marketing/supply companies, located in the Niger Delta region of Nigeria. The study population was petroleum business leaders who had strategic experience in solving petroleum shortage problems in the Nigerian downstream. Smith, Colombi, and Wirthlin(2013) posited that purposeful sampling allow scholars to select participants who will provide the best responses to address a study problem.O'Reilly and Parker (2013) agreed that qualitative scholars use sample size to guarantee the richness of information, and the number of participants depends on the subject and availability of resources. I attained data saturation by interviewing participants until no new information emerged. Researchers achieve data saturation when participants produce the same information during the interview process(O’Reilly \& Parker, 2013).

\subsection{Data Collection}

I was the primary instrument for data collection in this research. In qualitative studies, researchers must recognize themselves as the major instrument when conducting research (Haahr et al., 2014). I collected data using semi structured interviews, with open-ended questions, in a face-to-face setting. Bernard (2013), affirmed that semi structured interviews with open-ended questions are reliable instruments for generating responses from a participant in qualitative studies. Researchers use face-to-face interviews to generate information from participants to develop knowledge (Doody \& Noonan, 2013).

For methodological triangulation, I reviewed archival operational and policy documents in addition to the semi structured interviewsresponses from participants. Wahyuni(2012) noted that gathering data from different sources provide researchers with more information, check consistency and enhance the vigor of results. For Validity and Reliability of data; I employed member checking of the data collection instrument and the research process. Participants received a copy of my interpretation of transcribed interview to ensure correct representation of responses.

\subsection{Data Analysis}

I employed methodological triangulation process for the data analysis. Carter et al.(2014) posited that qualitative case study researchers use triangulation to test the validity of a study through the convergence of information from different sources. I analyzed the interviews and archived documents using QSR NVivo ${ }^{\circledR}$ computer-assisted qualitative data analysis software (CAQDAS) tool. Qualitative research analysis tools such as NVivo $^{\circledR}$ are useful in both data analysis, literature analysis, and data organization (Paulus, Lester, \& Britt, 2013).

I collected data by interviewing petroleum business leaders in the two organizations to obtain information that may lead to the provision of technological resource strategies for sustainable petroleum product supply in Nigeria. I allocated letters and numbers to each participant for anonymity purposes. The letter $L$ and a number represent petroleum business leaders (i.e., L1). I designated the two supply companies as company A and B.

\subsection{Discussions and Findings}

$\mathrm{Wu}$ (2013) affirmed that technological products (i.e., computers, software, communication equipment, and semiconductors) are increasingly being developed, thereby, bringing undeniable convenience to different aspects of the business. Setia, Venkatash, and Joglekar (2013) posited that the application of technology into 


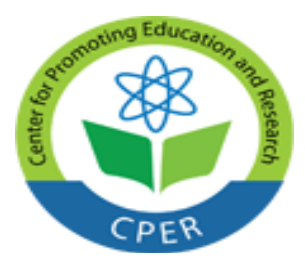

VOL: 5, ISSUE: 2

February/2019

E-ISSN: 2469-6501

(C) Center for Promoting Education and Research (CPER) USA

WWW.cpernet.org

organizations improves the entire business process. Besk and Seuring (2014) affirmed that the absence of technological communication and coordination in firms could lead to ineffective and inefficient performance. The petroleum supply chain operation involves technologically intensive activities in different environments across the world (Ahmad et al., 2016).

All participants affirmed that technology plays a key role in alleviating petroleum product scarcity. Participant L7B stated that the oil and gas industry is technology driven. All participants noted that technology is applied to all segments of the supply and value chain to achieve efficiency. Participants L5A and L9B emphasized that technology is applied in operations, such as: marine or vessel operations, discharge operations, tank farm operations, loading into trucks, motorized trucking, truck tracking, transportation, and dispensing in the retail outlets.

Participants L1A and L2A noted that different software is utilized in the nonoperational segment of the supply value chain. These segments include the accounts, sales, IT, security, safety, and administrative departments that use software to monitor operations, such as: sales, stock volume, re-order quantities, and logistics parameters.

Furthermore, Participant L5A explained that without technology, the private bulk storage depots cannot operate. The private depots operate with the aid of computer systems, measuring and dispensing instruments, safety instruments, fire extinguishers, fire arrestors, gas detectors, and gloves; besides several technological gadgets for improving the supply process like ERP, Microsoft package, and the other operational software. Participants L1A and L5A noted that other examples of software employed in the supply chain operations include power enterprise, micro-load software, Depot man, and Microsoft Dynamics. Ahmad et al. (2016) noted that petroleum business leaders apply technology for operations across all segments of the supply chain system. Also, organizations integrate work operations by aid of technology to enhance flexibility, share information, reduce cost, and improve performance (Rajaguru \& Matanda, 2013).

Organizations are adopting technologies to improve business efficiencies and increase value (Caniel, Lenaert, \& Gelderman, 2015). Information management is fundamental to every business organization, and firms are using IT to improve efficiency (Rajaguru \& Matanda, 2013; Nicho \& Muamaar, 2016). Participant L10B emphasized that, with technology, transactions are made faster and secured. Participant L10B noted that technology like computer and automation of processes, help to reduce time wastage in document processing and enhance communication with internal and external customers. Participants L4A, L9B, and L10B emphasized on the use of technological resources on truck tracking to prevent diversion of products from the assigned destination. According to participant L10B, the logistics segment uses technology such as tracking devices, speed limiters, and GSM phones to enhance the efficiency of truck diversion. Participant L7B noted that technology minimizes fraud and improves efficiency across the supply chain. Innovation, such as GSM phones, Internet, and computer systems, help to streamline business communication and offer opportunities and challenges (Adu, 2016).

According to participant L9B, technology helps petroleum depot operators and leaders to track records of stock, truck loading, and sales on a daily basis within the depot and the retail outlets. Sales operation and accounts must have the same records at all times (L9B). Also, participant L8B attested that organizations use technology to monitor products, both in trucks and underground in retail outlets. Some outlets use Automatic Tank Gauge, which is a control device for accurate underground discharge. Also, Participant L8B noted that for diesel consumption in trucks, there is equipment for monitoring fuels, which is cost control equipment. Do Nascimento and de Lucena (2017) noted that a number of technological equipment, when connected to the Internet, interact to share information. 


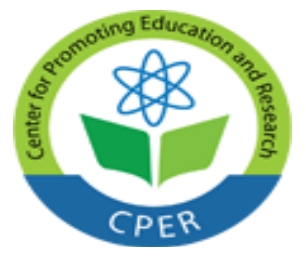

VOL: 5, ISSUE: 2

February/2019

E-ISSN: 2469-6501

(C) Center for Promoting Education and Research (CPER) USA

WWW.cpernet.org

Monday (2015) affirmed that Nigeria lacks the basic technological resources to effectively and efficiently manage the NDPSI. The lack of technological knowledge has resulted in refineries, oil infrastructures, and facilities that remain in a state of disrepair and moribund (Monday, 2015; Oladepo, 2014). Sixty percent of participants stated that Nigeria does not have the prerequisite technology to drive the oil and gas industry, and that Nigeria needs to import technology to meet up with the capacity utilization of the petroleum industry, especially the refineries. Also, $60 \%$ of participants agreed that there is a need for improvement or advancement in technology in Nigeria, as good technology will bridge the gap of supply shortages. Participants L2A and L4A emphasized that technology brings efficiency and effectiveness into the business process of the NDPSI.

All participants agreed that natural resources of crude oil would impart positively on the availability of petroleum products, which will enhance business development in Nigeria. Unfortunately, private depots do not refine the crude oil natural resources. Sixty percent of participants avowed that Nigeria lacks the basic technology to operate refineries. Monday (2015) affirmed on the lack of technological personnel in the NDPSI is a major factor affecting the performance of refineries and, hence, the supply shortages of refined petroleum products in Nigeria. The existing government refineries are moribund, coupled with the failure of the turnaround maintenance (TAM) to revive them. The oil and gas industry has technological resource problems, hence, the failure of TAM. Nigeria imports technological professionals and engineering organizations for major construction works in the NDPSI, especially for repairing refineries and TAM, to enhance the supply of refined petroleum products (Olukoju, 2014). Ninety percent of participants lamented that Nigerians do not enjoy the benefits of the endowed natural resources of crude oil, because the nation refineries operate below the expected capacity. According to participants L3A, L6B, and L7B, Nigeria consumes about 40 million litters of petroleum daily, while the refineries produce less than $20 \%$ of the quantity.

Eighty percent participants lamented that Nigeria export crude and imports refined petroleum products at international prices such that the fluctuation in the international petroleum prices affects product availability in Nigeria. Participants L1A, L2A, L6B and L7B emphasized that when crude oil price is high; procurement cost is high, which in most cases lead to scarcity of products in Nigeria. Also, $40 \%$ participants noted that if Nigeria has functional refineries, the availability of refined petroleum products will not depend on importation or international prices; instead, Nigeria will export refined products to earn foreign exchange and enhance economic development. Alaba and Agbalajobi (2014) stressed that the lack of efficiency in the existing Nigerian refineries resulted in the sourcing of petroleum products from abroad.

Participants L5A and L6B noted that the importation of refined petroleum product depletes Nigerian foreign reserves, which negatively affects economic development. Refining abroad leads to high cost, resulting from importation and associated cost (L6B). Seventy percent of participants agreed that, with the right technology, the Nigerian refineries would function, leading to the local refining of demanded products instead of importing. Aminu and Olawore (2014) advised Nigerian policy makers and leaders to employ technology in addressing problems of the NDPSI. In Table 4, I present the frequency at which participants mentioned the need for employing technology in all business operations of the NDPSI. 


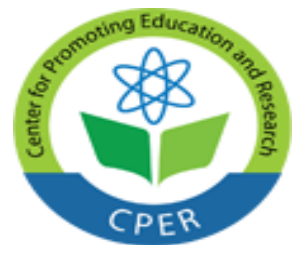

Table 1

Application of Technology in both Operational and Nonoperational Segments (Frequency)

\begin{tabular}{crc}
\hline Participants & Interview questions & Total number of references \\
\hline L1A & 3,7 & 4 \\
L2A & 1,7 & 3 \\
L3A & $1,3,7$, & 6 \\
L4A & 7 & 4 \\
L5A & $1,7,8$ & 7 \\
L6B & 7 & 4 \\
L7B & 7 & 3 \\
L8B & 7,12 & 6 \\
L9B & $1,3,7$ & 5 \\
L10B & 7,12 & 5 \\
\hline
\end{tabular}

\subsection{Archival Document Analysis}

I reviewed and analyzed the operational and policy statement documents of Company's A and Company's B (Appendix F \& G, respectively) regarding the application of technology in improving supplies in the NDPSI for economic development. The archival documents revealed that the organizations have a business strategy to use online software for job assignment, auditing, and HR operations. Also, Company A's archival document showed that the firm has a strategy to develop a sound basis for technological professionalism, through assurance and information to attain real-time solutions for efficiency. Caniel, Lenaert, and Gelderman (2015) posited that firms are implementing technologies to improve business efficiencies and increase value. Wu (2013) noted that to enhance a firm's performance, leaders should benchmark trends in the market place and maintain high technological links with supply chain partners. Furthermore, Kongoso (2015) advised that organizations should employ technology in their operations to check fraud, secure vital information, and improve performance.

\subsection{Application to Practice}

According to Monday (2015), Nigeria does not have the basic technology to effectively and efficiently manage the NDPSI. Participants emphasized on the application of technology to every segment of the NDPSI business, whether operational or nonoperational. All participants agreed that the NDPSI is technology driven. Organizational operational and nonoperational segments are interwoven with the aid of technological abilities (Rajaguru \& Matanda, 2013). Participants explained that business starts with the nonoperational segment, where the administrative and accounts personnel transact with banks to purchase products from abroad or the NNPC. The appropriate technological software is needed to aid these transactions. The ship-to-ship, tank farm, and retail outlet operations are all driven and interconnected by technology. Each of these segments applies software to achieve real-time and on-time operations within the firm. Integration of information systems across segment of organization has become the backbone of SCM as the process enhances information sharing and improves productivity (Rajaguru \& Matanda, 2013).

\subsection{Recommendations and Conclusion}

Refined petroleum product shortages are a menace to the business and economic development of Nigeria. 


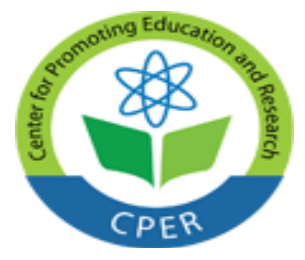

VOL: 5, ISSUE: 2

February/2019

E-ISSN: 2469-6501

(C) Center for Promoting Education and Research (CPER) USA

WWW.cpernet.org

(Aminu \& Olawore, 2014 Osuala, 2013). Technology application in the supply chain mechanism of the NDPSI is a sure way to improving supply efficiency. Considering the research findings, I recommend the following actions:

- For effectiveness and efficiency, leaders should apply the required technology to every segment of the supply value chain (i.e., operational and nonoperational segments).

- Petroleum business leaders should apply technology in marine or vessel operations, discharge operations, tank farm operations, loading into trucks, motorized trucking, truck tracking, speed limits, and dispensing in the retail outlets.

- Leaders should employ technology in accounts, administration, IT, security, safety, HR, marketing, and sales to monitor stock volume, re-order quantities, and logistics parameters and achieve real-time on-time operation for optimum productivity.

- Firms should apply technology for seamless communication and coordination of all segments of the supply chain to improve performance.

- Organizations should be involved in innovation and upgrade of existing technologies.

- Organizations should regularly collaborate with foreign firms to create processes and develop new technologies for both operational and nonoperational activities.

- Leaders should advice policy makers to employ technology in addressing the problems of the NDPSI.

Application of these strategies by business leaders will mitigate petroleum scarcity from the technological resource viewpoint as also researched by Itsekor (2018). The findings show that petroleum leaders should be involved in applying technology in all segments of the supply chain (operational and nonoperational), innovate and upgrade technologies, and advice policy makers to include technology in downstream supply policies. Petroleum business leaders implementing the appropriate technologies will enhance supply sustainability and improve business and economic growth in Nigeria.

\section{Acknowledgements}

Application of Technology in Mitigating Refined Petroleum Shortages in the Nigerian Downstream Petroleum Supply Industry' is one of the themes identified in my doctoral study. I am using this medium to disseminate this finding using a journal article. I appreciate my chair, Dr. Yvette Ghormley and all my committee members at the Walden University, USA, for their support and guidance towards my achieving this goal.

\section{References}

Adelabu, N. S. (2012). The political economy of oil deregulation in Nigeria's fourth republic: Prospects and challenges. Journal of Emerging Trends in Educational Research and Policy Studies, 3, 193-198.

Adu, C. A. (2016). Cashless policy and its effects on the Nigerian economy. European Journal of Business, Economics and Accounting, 4(2), 81-88.

Ahmad, W. N., Rezaei, J., Tavasszy, L. A., \& de Brito, M. P. (2016). Commitment to and preparedness for sustainable supply chain management in the oil and gas industry. Journal of Environmental Management, 180, 202-213.

Akinwotu, S. A. (2014). A comparative study of the discursive strategies in the media interviews of participants in the January 2012 fuel subsidy removal crisis in Nigeria. Journal of Arts and Humanities, 3(7), 21-33. 


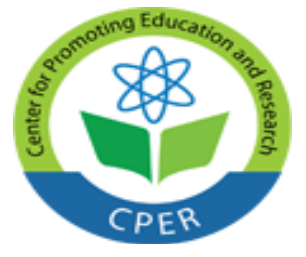

VOL: 5, ISSUE: 2

February/2019

https://ijbassnet.com/

E-ISSN: 2469-6501

(C) Center for Promoting Education and Research (CPER) USA

wWW.cpernet.org

Alaba, O. C., \& Agbalajobi, S. A. (2014). Evaluation of private refineries and depots in distribution of petroleum products in Nigeria. International Journal of Engineering and Technology, 4, 118-126.

Alimi, R. S., \& Fatukasi, B. (2014). The role of oil prices and real exchange rate on the output growth in Nigeria. International Journal of Research Economic, 3, 70-79.

Ambituuni, A., Amezaga, J., \& Emeseh, E. (2014). Analysis of safety and environmental regulations for downstream petroleum industry operations in Nigeria: Problems and prospects. Environmental Development, 9, 43-60.

Ambituuni, A., Amezaga, J. M., \& Werner, D. (2015). Risk assessment of petroleum product transportation by road: A framework for regulatory improvement. Safety Science, 79, 324-335.

Aminu, S. A., \& Olawore, O. P. (2014). Empirical investigation of challenges of distribution of premium motor spirit (PMS) in federal capital territory (FCT), Abuja and environs, Nigeria. InternationalJournal of Management Sciences and Humanities, 2(2), 11-38.

Aminu, S. A., \& Olayinka, K. A. (2014). Achieving petrol conservation through higher pump price in Nigeria: Evidence from the transport sector of Lagos State. International Journal of Management Sciences and Humanities, 2(2), 102-122.

Anifowose, B., Lawler, D., Horst, D., \& Chapman, L. (2014). Evaluating interdiction of oil pipelines at river crossings using Environmental Impact Assessments. Area, 46(1), 4-17.

Barney, J. (1991). Firm resources and sustained competitive advantage. Journal of Management, 17, 99-120.

Bernard, H. R. (2013). Social research methods: Qualitative and quantitative approaches (2nd ed.). Thousand Oaks, CA: Sage.

Beske, P., \& Seuring, S. (2014). Putting sustainability into supply chain management. Supply Chain Management: An International Journal, 19, 322-331.

Carter, N., Bryant-Lukosius, D., Dicenso, A., Blythe, J., \& Alan, J. (2014). The use of triangulation in qualitative research. Oncology Nursing Forum. 41, 545-547.

Caniëls, M. C., Lenaerts, H. K., \& Gelderman, C. J. (2015). Explaining the internet usage of SMEs: the impact of market orientation, behavioural norms, motivation, and technology acceptance. Internet Research, 25, 358-377.

Chigbu, U. S., Ubah, C. P., \& Chigbu, E. E. (2016). Deregulation of the petroleum downstream sector and Nigerian economy: An econometric investigation. International Journal of Business and Applied Social Science, 2 (9), 16-27.

Crook, T. R., \& Esper, T. L. (2014). Do resources aid in supply chain functioning and management? Yes, but more (and more precise) research is needed. Journal of Supply Chain Management, 50(3), 94-97.

David, A. C., Harrak, M. E., Mills, M., \& Ocampus, L. (2014). Oil spill covers: Linkages in petroleum product pricing policies in West African countries. The Journal of Developing Areas, 48, 329-363. 


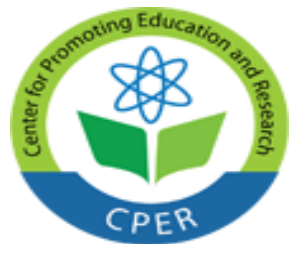

VOL: 5, ISSUE: 2

February/2019

https://ijbassnet.com/

E-ISSN: 2469-6501

(C) Center for Promoting Education and Research (CPER) USA

wWw.cpernet.org

Department of Petroleum Resources (2016). Operations. Retrieved from https://dpr.gov.ng/index

Doody, O., \& Noonan, M. (2013). Preparing and conducting interviews to collect data. Nurse Researcher, 20, 5, 28-32.

Dulami, H. A. M. (2014). The collapse of crude oil prices: Cyclical evolution or market manipulation? Economic Insight-Trends and Challenges, 66, 89-96.

Enuoh, R. O., \& Inyang, B. J. (2014). Effective management of Corporate Social Responsibility (CSR) for desired outcome: The Niger Delta issue in Nigeria. International Journal of Business Administration, $5(4), 32-38$.

Fowowe, B. (2014). Modeling the oil price-exchange rate nexus for South Africa. International Economics, 140, 36-48.

Gonzalez, A. (2016). Poverty, oil, and corruption: The need for a quad-sectordevelopment partnership (QSDP) in Nigeria's Niger Delta. Development Policy Review. 34, 509-538.

Haahr, A., Norlyk, A., \& Hall, E. O. (2014). Ethical challenges embedded in qualitative research interviews with close relatives. Nursing Ethics, 21, 6-15.

Harrison III, R. L. (2013). Using mixed methods designs in the journal of business research, 1990-2010. Journal of Business Research, 66, 2153-2162.

Hitt, M. A., Xu, K., \& Carnes, C. M. (2016). Resource based theory in operations management research. Journal of Operations Management, 41, 77-94.

Igbinovia, P. E. (2014). Oil thefts and pipeline vandalization in Nigeria. Ibadan, Nigeria: Safari Books Ltd

Ijaiya, H. (2014). Challenges of corporate social responsibility in the Niger Delta region of Nigeria. Journal of Sustainable Development Law and Policy (The), 3, 60-71.

Kongnso, F. (2015). Best practices to minimize data security breaches for increased business performance. Walden Dissertation and Doctoral studies. Available at www.scholarworks@waldenu.edu

Itsekor, L. U. (2018). Mitigating petroleum product shortages in the Nigerian downstream petroleum supply industry. Walden Dissertation and Doctoral Studies. https://ezp.waldenulibrary.org/login?url=https://searchproquest-com.ezp.waldenulibrary.org/docview/2033044375?accountid=14872. Also available at www.scholarworks@waldenu.edu

Maniruzzaman, A. F. M., \& Jasimuddin, S. M. (2016). Resource nationalism spectre hovering over the oil industry: The transnational corporate strategies to tackle resource nationalism risks. Journal of Applied Business Research, 32(2), 387-400.

Marshall, C., \& Rossman, G. (2016). Designing qualitative research (6th ed.). Thousand Oaks, CA: Sage.

Monday, J. U. (2015). Local content policy, human capital development and sustainable business performance in the Nigerian oil and gas industry. Journal of Management and Sustainability, 5(1), 75-83.

Nicho, M., \& Muamaar, S. (2016). Towards a taxonomy of challenges in an integrated IT governance framework implementation. Journal of International Technology and Information

Management, 25(2), 1-33. 


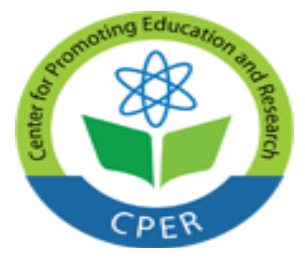

VOL: 5, ISSUE: 2

February/2019

E-ISSN: 2469-6501

(C) Center for Promoting Education and Research (CPER) USA

WWW.cpernet.org

Nigerian National Petroleum Corporation. (2016). Profile/products. Retrieved from www.nnpcgroup.com Odeh, A. M. (2011). Deregulation policy in the downstream oil and the Nigerian economy. Journal of Social Science and Public Policy, 3, 87-100.

Okwanya, I., Moses, O., \& Pristine, J. M. (2015). An Assessment of the impact of petroleum subsidy on consumer price index in Nigeria. Global Journal of Interdisciplinary Social Sciences, 4(1), 36-39.

Oladepo, I. O. (2014). Evaluation of petroleum products marketing in a globalizing economy: Conceptual evidence from Nigeria. British Journal of Marketing Studies, 2 (2), 71-81.

Olukoju, A. (2014). The challenges of sustainable development in Nigeria. InternationalJournal of Management Sciences and Humanities, 2(2), 1-10.

O'Reilly, M., \& Parker, N. (2013). Unsatisfactory Saturation: A critical exploration of the notion of saturated sample sizes in qualitative research. Qualitative Research, 13, 190-197.

Osuala, U. S. (2013). The sublimeness of sleaze in the NNPC in the fourth republic, 1999-2007: A historical conspectus. Journal of Culture, Society and Development, 2, 52-59.

Paulus, T., Lester, J., \& Dempster, P. (2013). Digital tools for qualitative research. L.A. Sage.

Punch, K. F. (2013). Introduction to social research: Quantitative and qualitative approaches. Thousand Oaks, CA: Sage.

Rajaguru, R., \& Matanda, M. J. (2013). Effects of inter-organizational compatibility on supply chain capabilities: Exploring the mediating role of inter-organizational information systems (IOIS) integration. Industrial Marketing Management, 42, 620-632.

Sancha, C., Longoni, A.,\& Giménez, C. (2015). Sustainable supplier development practices: Drivers and enablers in a global context. Journal of Purchasing and Supply Management, 21(2), 95-102.

Setia, P., Venkatesh, V., \& Joglekar, S. (2013). Leveraging digital technologies: Howinformation quality leads to localized capabilities and customer serviceperformance. MIS Quarterly, 37, 565-590.

Smith, R. A., Colombi, M. J., \& Wirthlin, R. W. (2013). Rapid development: A contentanalysis comparison of literature and purposive sampling rapid reaction projects. Procedia Computer Science, 16, 475-482.

Tobor, J. O. (2014). Urhobo culture and the amnesty program in Niger Delta, Nigeria: An ethnographic case study. Walden Dissertation and Doctoral Studies. Retrieved from www.scholarworks@waldenu.edu

Vempatapu, B. P., \& Kanaujia, P. K. (2017). Monitoring petroleum fuel adulteration: A review of analytical methods. TrAC Trends in Analytical Chemistry, 92, 1-11.

Wahyuni, D. (2012). The research design maze: Understanding paradigms, methods, and methodologies. Journal of Applied Management Accounting Research, 10, 69-80.

Wilson, G. (2014). The Nigerian state and oil theft in the Niger Delta region of Nigeria. Journal of Sustainable Development in Africa, 16(1), 69-81.

$\mathrm{Wu}, \mathrm{G}$. C. (2013). The influence of green supply chain integration and environmental uncertainty on green innovation in Taiwan's IT industry. Supply Chain Management: An International Journal, 18, 539-552.

Zimmermann, F., \& Foerstl, K. (2014). A meta-analysis of the "purchasing and supply management practiceperformance Link". Journal of Supply ChainManagement, 50(3), 37-54. 